\title{
Diels-Alder Cycloaddition in the Synthesis of 1-Azafagomine, Analogues, and Derivatives as Glycosidase Inhibitors
}

\author{
Daniela A. L. Salgueiro, Cristina E. A. Sousa, A. Gil Fortes, M. José Alves* \\ Departamento de Quimica, Universidade do Minho, Campus de Gualtar, 4710-057 Braga, Portugal
}

\begin{abstract}
This comprehensive review deals with the synthesis of 1-azafagomine, analogues, and derivatives having the Diels-Alder cycloaddition as the key step. Most of the compounds referred are racemic or have been resolved by lipase transesterification. There are two asymmetric cycloadditions leading to 1-azafagomine or to an analogue. In one case both enantiomers of 1-azafagomine were prepared together with a pair of derivatives. The study comprises glycosidase inhibition studies of the target compounds to a set of glycosidic enzymes, and evidenced molecular features that enhance or diminish their activity as glycosidase inhibitors.
\end{abstract}

Keywords: azafagomine, biological activity, Diels-Alder cycloaddition, glycosidase inhibitors, azasugars. 
Summary

1. Introduction

2. Synthesis of racemic 1-azafagomine, and analogues

2.1 Synthesis of 1-azafagomine, and monocyclic analogues

2.2 Synthesis of fused bicyclic azafagomine analogues (castanospermine analogues)

3. Chiral 1-azafagomines, derivatives, and analogues

3.1 Chemoenzymatic resolution of 1-azafagomine, and analogues

3.2 Synthesis of homochiral 1-azafagomine, derivatives, and analogues

\section{Introduction}

Glycosidases are crucial enzymes in all living organisms because they control many biological processes. Potent and selective inhibition of these enzymes is a very important topic that deals with finding the right chemical entities, mainly entrusted to synthetic chemists. Azasugars are major targets as glycosidase inhibitors due to their ability to mimic the transition state of saccharides in the enzymes. Two azasugars are currently being used in clinics: Miglitol against diabetes type II from Gliset ${ }^{\circledR}$, and Miglustat against Gaucher disease from Zavesca ${ }^{\circledR}$. Many other azasugars had showed to be active against diabetes [1], cancer [2], hepatitis [3], Gaucher's disease [3], AIDS [4,5] and influenza [6]. In some cases the target azasugars reached advanced clinical trials, as did D-swainsonine that passed till clinical trial phase II [7], but for one or another undesirable secondary effects they have failed to be introduced as pharmaceuticals. Figure 1 shows the five groups of natural azasugars known. This brief review deals only with synthetic piperidine and indolizidine analogues, containing a N-N unit incorporated in the molecules, in which the crucial process in its synthesis is a Diels-Alder cycloaddition.<smiles>OC[C@H]1N[C@@H](O)[C@H](O)[C@H](O)[C@@H]1O</smiles>

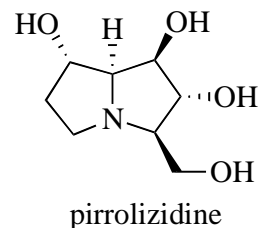

pirrolizidine
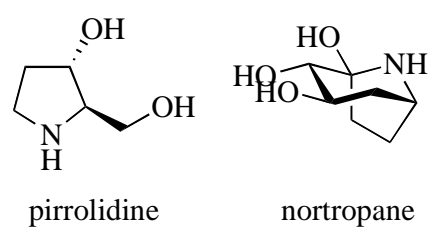

Figure 1- Natural azasugar groups.

Azasugars are able to disguise sugars because the cleavage of the anomeric group develops a positive charge that can be stabilized either by oxygen or nitrogen atoms, attached to the anomeric carbon. Figure 2 shows the developing positive charges on the transition state of glucosides in glucosidases active sites. The cleavage of the anomeric oxygen group develops a positive charge at the anomeric carbon $(\mathbf{A})$, and the resonance effect creates a second transition state $(\mathbf{B})$. Which of these transition states seems more important it depends on the enzyme, although it is likely that most enzymes have a component of each [8-10]. 


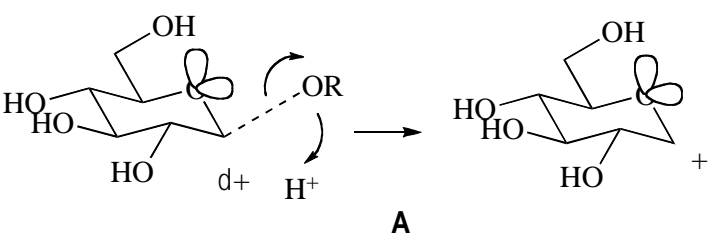

A

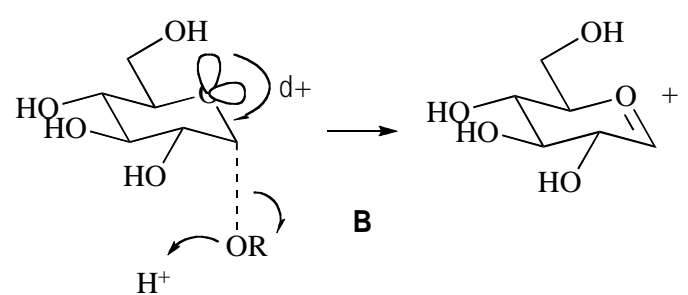

$\mathrm{H}^{+}$

Figure 2- Two possible transition states of a D-glucose unit in a saccharide.

It had been explained that the stereoelectronic effect that assists the $\alpha$-cleavage is due to the antiperiplanar disposition of the axial electron pair at the glucopyranose oxygen atom to give type B transition state, with the positive developing charge at the oxygen. On the other hand, the $\beta$-cleavage has to occur with no stereoelectronic assistance, giving transition state type $\mathbf{A}$ with the positive charge developing at the anomeric carbon atom [11]. (Figure 2) As a consequence glucose analogues that develop a positive charge at the oxygen/nitrogen atoms will be $\alpha$-inhibitors, and those that develop a positive charge on the anomeric carbon will be $\beta$-inhibitors.

\section{Synthesis of racemic 1-azafagomine, and analogues}

$( \pm$ )-1-Azafagomine $(\mathbf{1})$ potently inhibits yeast $\alpha$-glucosidase and almond $\beta$-glucosidase with very low $\mathrm{K}_{i}$ values as will be presented ahead. This means that there is a close connection in the ability of 1azafagomine to accept a proton at the active site of the enzyme and the transition states $\mathbf{A}$ and $\mathbf{B}$. In fact the mixture of the hydrazonium ions clearly resemble transition states $\mathbf{A}$ and B. (Figure 3) On this basis is to be expected that they will fit well in the active site of $\alpha$-and $\beta$-glucosidases, explaining the potential of such compounds over these enzymes.



A<smiles>OC[C@H]1[O+]=C[C@@H](O)[C@@H](O)[C@@H]1O</smiles>

B<smiles>OC[C@H]1N[NH2+][C@H](O)[C@H](O)[C@H]1O</smiles><smiles>OC[C@H]1[NH2+]N[C@@H](O)[C@@H](O)[C@@H]1O</smiles>

Figure 3- Structural resemblance between glucose transition states $\mathbf{A}$ and $\mathbf{B}$ with the two hydrazonium ions of protonated 1-azafagomine.

\subsection{Synthesis of 1-azafagomine, and monocyclic analogues}

Racemic 1-azafagomine ( \pm )-1 was obtained through a synthetic sequence based on a Diels-Alder cycloaddition between achiral materials: 2,4-pentadien-1-ol (2) and 4-phenyl-1,2,4-triazole-3,5-dione (PTAD, 3). The racemic cycloadduct 4 was epoxidized with trifluoromethyl(methyl)dioxirane generated in situ to furnish a 3:1 ratio of isomers, from which the major epoxide, $\mathbf{5}$, was isolated in $62 \%$ yield. The hydrolysis of epoxide 5 under perchloric acid afforded triol 6 in $73 \%$ with a high 
degree of stereoselectivity. Treatment of $\mathbf{6}$ with hydrazine at $100{ }^{\circ} \mathrm{C}$ gave finally compound $( \pm)-\mathbf{1}$ in $84 \%$ yield [11]. (Scheme 1)<smiles>C=C/C=C\COC</smiles>

2<smiles>O=c1n(-c2ccccc2)c(=O)n2n1C[C@@H](O)[C@@H](O)C2CO</smiles>

6<smiles>CCC1C=CCn2c(=O)n(-c3ccccc3)c(=O)n2C1</smiles>

4


$62 \%$ O $\underset{100{ }^{\circ} \mathrm{C}, 84 \%}{\stackrel{\mathrm{NH}_{2} \mathrm{NH}_{2}}{\longrightarrow}}$<smiles>OCC1NNCC(O)C1O</smiles>

$( \pm)-1$<smiles>O=c1n(-c2ccccc2)c(=O)n2n1CC1CCCC2C1CO</smiles>

5

Scheme 1- Synthesis of racemic 1-azafagomine 1.

A high biological activity was found in racemic 1-azafagomine, inhibiting both $\alpha$ - $\square$ and $\beta$-glucosidases. The almond $\beta$-glucosidase inhibition is demonstrated by the $\mathrm{K}_{i}=0.65 \mu \mathrm{M}$ at $\mathrm{pH}=6.8$, but curiously, the results are not much different with $\mathrm{pH}$ ranging from 5.0 to 7.5: at $\mathrm{pH}=5.0, \mathrm{~K}_{i}=0.76 \mu \mathrm{M}$, and $\mathrm{pH}=7.5$, $\mathrm{K}_{i}=1.09 \mu \mathrm{M}$. To explain the independence of the inhibition potential of 1-azafagomine (1) to the medium $\mathrm{pH}$, compound $( \pm)-\mathbf{1}$ was protonated with aqueous acidic solution and titrated with $\mathrm{NaOH}$; the $\mathrm{pK}_{a}$ was revealed to be 3.9. Hydrazine is very weak base, largely unprotonated even at $\mathrm{pH}=5.0$. This means that the unprotonated 1-azafagomine is the enzyme substrate even at $\mathrm{pH}=5$. 1-Azafagomine is also a potent inhibitor of yeast $\alpha$-glucosidase $\mathrm{K}_{i}=3.9 \mu \mathrm{M}$ at $\mathrm{pH}=6.8$ [11]. Isomaltase from backer's yeast and phosphorylase A are too highly inhibited by 1-azafagomine with $\mathrm{K}_{i}=1.06 \mu \mathrm{M}$ and $\mathrm{IC}_{50}=$ $13.5 \mu \mathrm{M}$ respectively. Other glycosidases were tested including $\alpha-/ \beta$-galactosidases and $\alpha$ mannosidases, but the results were very poor. Interestingly compound 1 combines the strong $\alpha$ inhibition of deoxynojirimycine (DNJ) with the strong $\beta$-inhibition of isofagomine showing that 1 azafagomine is able to mimic both the transition state $\mathbf{A}$ and $\mathbf{B}$, and can be considered a hybrid of those azasugars. But, on the contrary, deoxynojirimycine and isofagomine are highly dependent of the $\mathrm{pH}$ experiment, which agrees with their much higher basicity. (See Table 1)

Pyridazines $\mathbf{7}$ and $\mathbf{8}$ do not have the configuration of any natural sugar, but they were moderately competitive inhibitors of $\beta$-glucosidase and $\alpha$-mannosidase; compound $\mathbf{7}$ is in some extent also a moderate inhibitor of $\beta$-galactosidase. Compound 7 was obtained in $79 \%$ yield by osmilation of compound 4; compound 8 was obtained in $55 \%$ overall yield, following the steps described in scheme 1 , but using piperylene as the diene. (Figure 4) 
<smiles>OC[C@H]1NNC[C@@H](O)[C@@H]1O</smiles>

$( \pm)-7$<smiles>C[C@H]1NNC[C@H](O)C1O</smiles>

$( \pm)-8$

Figure 4- Structures of compounds $( \pm)-7$ and $( \pm)-8$.

Using piperylene or 1,3-butadiene as dienes and PTAD as dienophile, were obtained cycloadducts 9a and 9b [12]. The synthetic process includes first the synthesis of the oxirane with trifluoromethyl(methyl)dioxirane which was then treated with acetic anhydride in acetic acid in the presence of trifluoroboro etherate to yield compounds 10a (80.8\%) and 10b as 6 (trans) : 1 (cis) mixture of isomers $(80.9 \%)$. The diacetates were deprotected with sodium methoxide in methanol, followed by hydrazinolysis to afford compound 11a (56 \%) and 11b (35\%) over the two final steps [12]. (Scheme 2)<smiles>[R]C1C=CCn2c(=O)n(-c3ccccc3)c(=O)n21</smiles>

9a, $\mathrm{R}=\mathrm{H}$ $9 \mathrm{~b}, \mathrm{R}=\mathrm{Me}$<smiles>CCOC(=O)CC(C(=O)O)C(C)(C)C</smiles>
$\mathrm{BF}_{3} \cdot \mathrm{Et}_{2} \mathrm{O}$

Scheme 2- Synthesis of racemic compounds 11a and 11b.<smiles>[R]C1NNC[C@@H](O)[C@@H]1O</smiles>

11a, $\mathrm{R}=\mathrm{H}$

$11 \mathrm{~b}, \mathrm{R}=\mathrm{Me}$

The biological activity of compound $\mathbf{1 1 b}$ as a pure enantiomer $(3 R, 4 R, 5 R)$ [13] is one order of magnitude less active than $( \pm)$-1-azafagomine relatively to $\beta$-glucosidase $\left(\mathrm{K}_{i}=3.0 \mu \mathrm{M}\right)$ and to $\alpha$ glucosidase $\left(\mathrm{K}_{i}=92.0 \mu \mathrm{M}\right)$, and 4 times less active than isomaltase $\left(\mathrm{K}_{i}=4.0 \mu \mathrm{M}\right)$. Compound 11a shows a much lower activity than $( \pm)$-1-azafagomine. (See Table 1 )

To investigate the role of the hydroxyl groups in the binding to the enzyme and find if other groups could successfully substitute the hydroxyl groups, fluoride, amino, and hydrazine were introduced at position 3. Fluorine is a bioisostere of the hydroxy group with similar polarity and shape [14]. The amino group was introduced because it strongly enhanced the activity of neuraminic acid derivatives on neuraminidase and the same trend could happen with 1-azafagomine derivatives relatively to glycosidases [15].

The hydroxy group at C-3 in compound $\mathbf{1}$ was displaced with fluorine by using the synthetic intermediate epoxide 5. Reaction of compound $\mathbf{5}$ with $\mathrm{HF}$ and pyridine furnished a fluorinated compound, which was peracetylated to promote isolation giving compound $\mathbf{1 2}$ in $68 \%$ yield. Deacetylation of $\mathbf{1 2}$ with sodium methoxide followed by hydrazinolysis yield compound $\mathbf{1 3}$ (28\%) together with compound $14(50 \%)$ as by-product. It had been demonstrated that the fluorine work as a leaving group under hydrazinolysis conditions, giving back the epoxide then opening again with hydrazine. (Scheme 3) 
The amino group at the position 3 was introduced by opening the epoxide with trimethylsilylazide followed by reduction of the azido group and hydrazinolysis of the urazol moiety. Compound $\mathbf{1 5}$ was obtained in $69 \%$ yield after the 3 steps. [16, 17](Scheme 3$)$<smiles>O=c1n(-c2ccccc2)c(=O)n2n1C[C@H]1O[C@H]1C2CO</smiles>

$$
\text { 1) } \mathrm{HF} /
$$

<smiles>CCCC1NNC[C@@H](N)[C@H]1O</smiles>

$( \pm)-15$
1) $\underset{\mathrm{NaOMe}}{\mathrm{NH}_{2} \mathrm{NH}_{2}}$<smiles>OC[C@H]1NNCC(F)[C@@H]1O</smiles>

$( \pm)-\mathbf{1 3}$ $28 \%$<smiles>N[C@@H]1CNN[C@H](CO)[C@@H]1O</smiles>

$( \pm)-14$ $50 \%$

Scheme 3- Synthesis of 3-fluoro-, 3-hydrazinyl-, and 3-amino-1-azafagomines.

Displacement of the primary hydroxyl group in compound $\mathbf{5}$ with fluorine was carried out with diethylaminosulfur trifluoride (DAST). This reagent is known to be a powerful reagent for direct displacement of 6-hydroxyl group for fluorine in unprotected glucosides. The fluorine compound, 16, was obtained with $70 \%$ yield. The epoxide hydrolysis occurs under aqueous perchloric acid and is followed by hydrazynolysis with defluorination to give compound $\mathbf{1 7}$ as the only product formed in $27 \%$ yield from 16. [17] (Scheme 4)

Oi:<smiles>O=c1n(P)c(=O)n2n1C[C@H]1C[C@H]1[C@H]2CO</smiles>
(士)-5

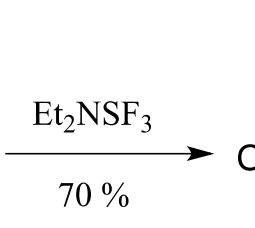

O, 16<smiles>O=c1n(-c2ccccc2)c(=O)n2n1C[13CH]1C[13C@@H]2[C@@H]1CF</smiles>

1) $\mathrm{HClO}_{4}$

2) $\mathrm{NH}_{2} \mathrm{NH}_{2}$<smiles>[13CH3]</smiles>

$27 \%$

Scheme 4- Attempt to substitute the hydroxymethyl group for fluoromethyl of 1-azafagomine.

Compound $\mathbf{1 3}$ as is shown in the table 1 is poor inhibitor of both the $\alpha$ - and $\beta$-glucosidases which suggests that the hydroxy group binds in the enzyme as a proton donor rather than a proton acceptor, which of course the fluoride atom has no ability to do. The substitution of the hydroxyl group for the amino group (compound 15) has shown a diminution of activity either to $\alpha$ - and $\beta$-glucosidases. The authors also concluded that the exocyclic amino group do not act as a hydrogen acceptor and its hydrogen donor ability is not affected by protonation. As happen with 3-amino-isofagomine [16] the amino group is acting as a poor hydrogen-bond donor compared to the hydroxyl group at the same 
position. Comparing 15 to the fluoro analogue $\mathbf{1 3}$ to which no hydrogen bond donor effect can be described it seems that the inhibitory potential of compound $\mathbf{1 5}$ is between the excellent hydrogen bond donor ability of compound $\mathbf{1}$ and the poor effect displayed by compound $\mathbf{1 3}$.

Table 1: Inhibition constants $\left(\mathrm{K}_{i}\right)$ in $\mu \mathrm{M}$ of various enzymes on target compounds measured at $25^{\circ} \mathrm{C}$.

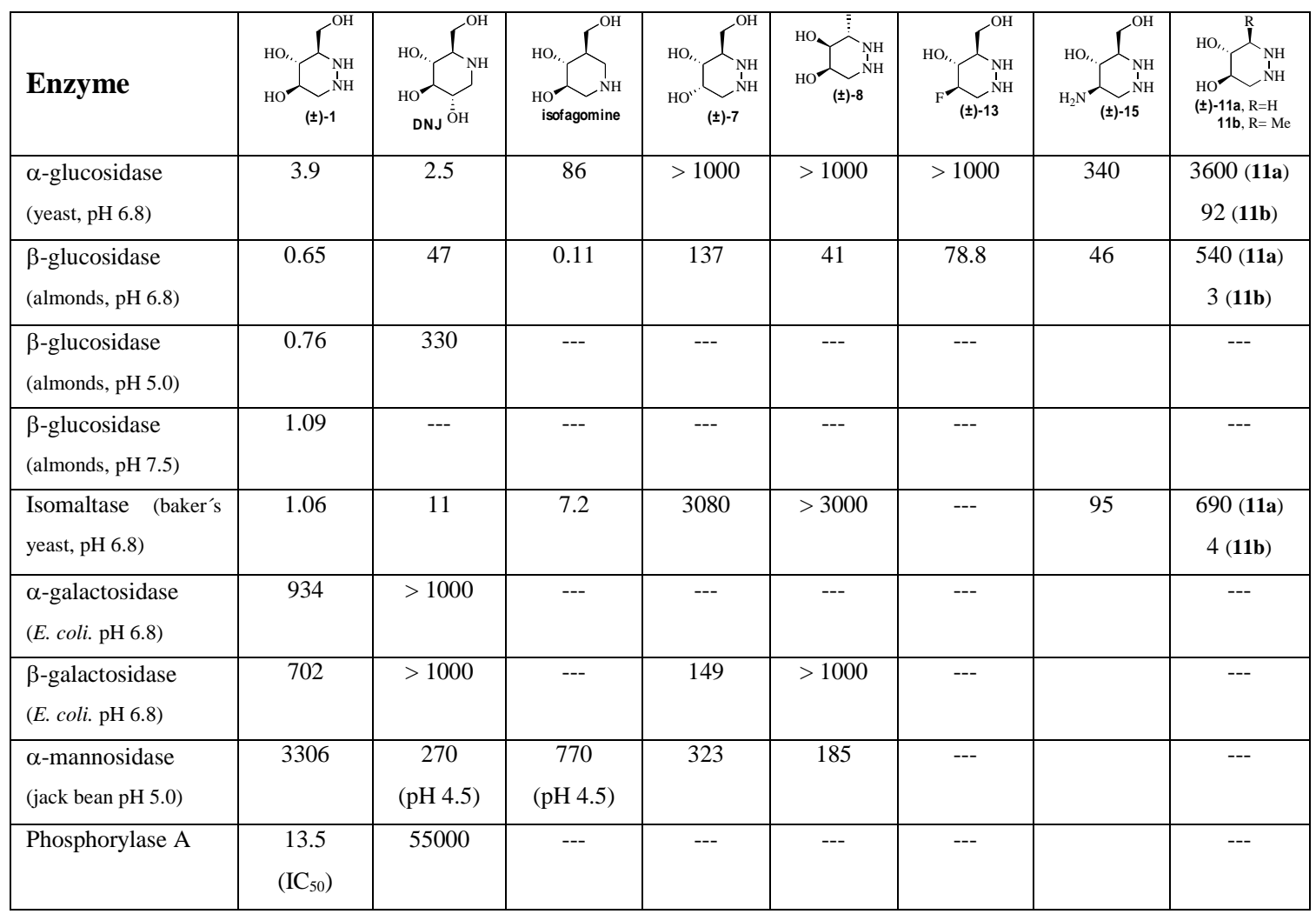

\subsection{Synthesis of fused bicyclic azafagomine analogues (castanospermine analogues)}

Two epimers of 5-aza-6-deoxycastanospermine analogues were obtained through Diels-Alder cycloaddition in the first step, from 5-benzyloxy-7-acetoxyhepta-1,3-diene 18 and PTAD [18]. (Scheme 5)<smiles>C=C/C=C\C(CCOC(C)=O)OCCC</smiles>

18<smiles></smiles>

$( \pm)-19$<smiles></smiles>

$( \pm)-\mathbf{2 0}$

$35 \%$ $46 \%$

Scheme 5- Cycloaddition of the diene 18 to PTAD. 
Each of the epimeric adducts $( \pm)-\mathbf{1 9}$ and $( \pm)$-20 underwent functional group transformations to give the azacastanospernine analogues. Scheme 6, briefly summarizes the synthetic sequence of one of the epimers, compound $( \pm)-26$.

Compound ( \pm )-19 was subjected to epoxidation followed by ring opening in the presence of trifluoroboro etherate, and acetic anhydride / acetic acid. The anti relationship of the acetyl groups was obtained, as expected. The acetyl groups were removed in compound $\mathbf{2 1}$ with sodium metoxide/methanol. Oxidation with TEMPO and sodium hypochlorite gave $\delta$-lactone 22. Reduction with diisobutylaluminium hydride, followed by acetylation with acetic anhydride in the presence of triethyamine and 4-dimethylaminopyridine afforded compound 23. Treatment of 23 with benzylic alcohol in the presence of trifluoroboro etherate gave the acetal 24. This compound was deacetylated and then treated with hydrazine to give 25. Hydrogenolysis under $\mathrm{Pd} / \mathrm{C}$ in methanol cleaved the benzyl groups and turn the aldehyde function free to suffer a reductive amination forming 5-aza-6deoxycastanospermine 26. (Scheme 6)<smiles>CC(=O)OCC[C@H](OCc1ccccc1)[C@@H]1C=CCn2c(=O)n(-c3ccccc3)c(=O)n21</smiles>

$( \pm)-19 \quad \mathrm{O}$<smiles>CC(=O)OCC[C@H](OCc1ccccc1)[C@H]1C[C@@H]2CN1C(=O)N(c1ccccc1)C2=O</smiles>

$\mathrm{O}$

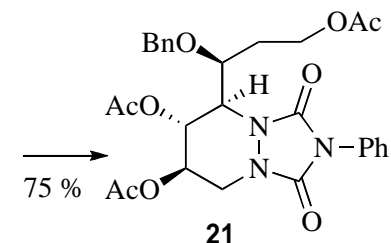

21<smiles>CCCO[C@H]1Cn2c(=O)n(-c3ccccc3)c(=O)n2[C@H]2[C@@H]1OC(=O)C[C@H]2OC(C)=O</smiles>

22<smiles>O[C@H]1CN[NH+]2CC[C@@H](O)[C@@H]2[C@@H]1O</smiles>

26<smiles>O[C@H]1CNNC2[C@H](OCc3ccccc3)C[C@@H](OCc3ccccc3)O[C@H]21</smiles>

25<smiles>CC(=O)OC1Cn2c(=O)n(-c3ccccc3)c(=O)n2[C@@H]2[C@@H]1O[C@H](OCc1ccccc1)C[C@H]2O</smiles>

24 $\downarrow 70 \%$<smiles>CC(=O)OC1Cn2c(=O)n(-c3ccccc3)c(=O)n2[C@H]2[C@@H]1O[C@@H](OC(C)=O)C[C@H]2Cc1ccccc1</smiles>

23

Scheme 6- Formation of 5-aza-6-deoxycastanospermine analogue 26.

Compound ( \pm )-21 was subjected to deacetylation with sodium metoxide, followed by hydrazinolysis to yield the triol 27. The unprotected monocyclic 28 was obtained by hydrogenation under $\mathrm{Pd}$ in the presence of $\mathrm{HCl}$. (Scheme 7) The same sequence was applied to the product obtained from compound $( \pm)$-20: epoxidation followed by epoxide opening in the presence of trifluoroboro etherate, under acetic anhydride / acetic acid to yield the respective diastereomer 29. (See Table 2)

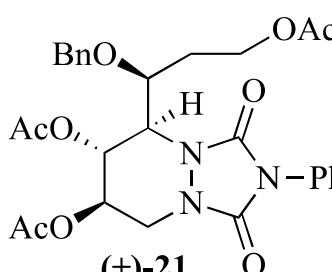

$( \pm)-21 \quad \mathrm{O}$

$$
\underset{\text { 2. } \mathrm{NH}_{2} \mathrm{NH}_{2}}{\stackrel{\mathrm{NaOMe}}{\longrightarrow}}
$$
$100 \%$

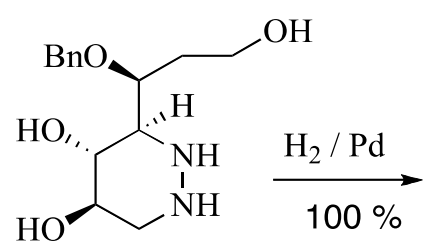

27<smiles>OCC[C@@H](O)[C@H]1NNC[C@@H](O)[C@@H]1O</smiles>

28

Scheme 7- Synthesis of monocyclic compound 28. 
Epimer 26 showed a poor $\alpha$-glucosidase inhibition to the yeast source $\left(K_{i}>600 \mu \mathrm{M}\right)$ and a much better inhibition to $\alpha$-glucosidase from rice $\left(\mathrm{K}_{i}=15 \mu \mathrm{M}\right)$. The values for $\beta$-glucosidase obtained from almonds are also good $\left(\mathrm{K}_{i}=10 \mu \mathrm{M}\right)$. Even so the best result of castanospermine is for $\alpha$-glucosidase from rice $\left(\mathrm{K}_{i}=0.015 \mu \mathrm{M}\right)$, three orders of magnitude more active than $\mathbf{2 6}$ for the same enzyme. The epimer of 26, 30 having the hydroxyl group of the five-membered ring at the equatorial position showed poorer values to the same enzymes: between $\mathrm{K}_{i}=570-690 \mu \mathrm{M}$, except for $\alpha$-glucosidase from rice to which the value is even poorer $K_{i}>1000 \mu \mathrm{M}$. This strongly suggests a clear preference of glucosidases for binding substrates with the hydroxy group at the axial position [18]. (Figure 5)

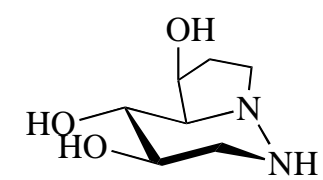

26

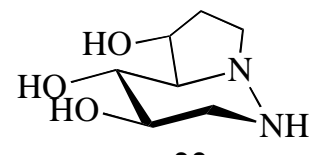

30

Figure 5- Haworth representations of 5-aza-6-deoxy castanospermine analogues.

The best results obtained for compounds $\mathbf{2 9}$ and $\mathbf{3 0}$ goes for $\boldsymbol{\alpha}$-glucosidases either from rice and yeast, even so the $\mathrm{K}_{i}$ are between 150 and $380 \mu \mathrm{M}$.

Table 2: Inhibition constants $\left(\mathrm{K}_{i}\right)$ in $\mu \mathrm{M}$ of target compounds with various enzymes, measured at $25^{\circ} \mathrm{C}$ and $\mathrm{pH} 6.8$, unless noted otherwise.

\begin{tabular}{|c|c|c|c|c|}
\hline Compound & $\begin{array}{c}\alpha \text {-glucosidase } \\
\text { (yeast) }\end{array}$ & $\begin{array}{l}\alpha \text {-glucosidase } \\
\text { (rice) }\end{array}$ & $\begin{array}{c}\text { Isomaltase } \\
\text { (yeast) }\end{array}$ & $\begin{array}{c}\beta \text {-glucosidase } \\
\text { (almonds) }\end{array}$ \\
\hline & 25 & $0.01(\mathrm{pH}$ not given $)$ & 11 & 47 \\
\hline & $>1500$ & $0.015(\mathrm{pH}$ not given $)$ & --- & $1.5(\mathrm{pH} 5.0)$ \\
\hline & 2.0 & 6 & 0.27 & 0.33 \\
\hline & $>600$ & 15 & 79 & 10 \\
\hline & 570 & $>1000$ & 550 & 690 \\
\hline & 275 & 250 & $>1000$ & 660 \\
\hline & 380 & 150 & $>1000$ & 820 \\
\hline
\end{tabular}




\section{Chiral 1-azafagomines, derivatives, and analogues}

\subsection{Chemoenzymatic resolution of 1-azafagomine, and analogues}

Racemic 1-azafagomine described in scheme 1 was submitted to biocatalytic kinetic resolution using lipases [19]. An array of lipases was screened with poor results. Literature [20,21] refers a considerable number of reports using lipases for hydroxymethyl piperidines resolution; in all cases a less bulky group was attached at the nitrogen atom. And so, a parallel cycloaddition using 4-methyl-1,2,4triazole-3,5-dione (MTAD), instead of PTAD, prepared in situ from methyl urazol and tert-butyl hypochlorite, was used as dienophile. The procedure gave cycloadduct 31 in $87 \%$ yield. (Scheme 8)

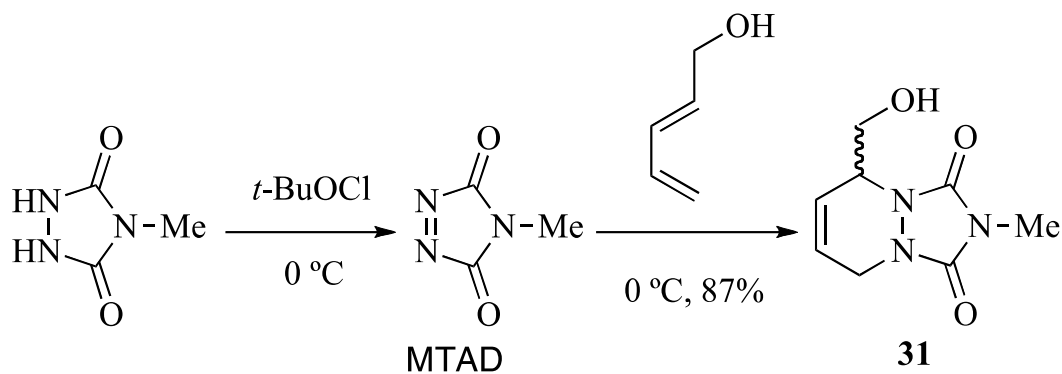

Scheme 8- Synthesis of cycloadduct 31.

Lipase-catalysed transesterification of compound $\mathbf{3 1}$ used vinyl acetate as the acetyl donor. Two enzymes out of over 20 were selected: Candida antartica lipase showed a good conversion but low selectivity; the best selectivity was achieved from lipase R (obtained from Penicillium roqueforti) after $17 \mathrm{~h}(12 \%$ conversion, $96 \%$ ee). The scale-up of the reaction with lipase $\mathrm{R}$ turned the process to be much slower, being stopped after $\mathrm{ca} 40 \%$ conversion. This provides compound $(S)$-32 in $38 \%$ yield and $86 \% e e$ and $(R)-\mathbf{3 1}$ in $60 \%$ yield and $59 \% e e$ [18]. (Scheme 9) The enantiopurity of the enantiomer (S)-32 could not be improved by crystallization, but after saponification of $(S)-\mathbf{3 2},(S)$-31 was obtained in enantiopure form. Unreacted compound 31, from the crude enzyme esterification, was enantiomerically enriched in the $(R)$-alcohol. The sample was treated with Candida antartica lipase, which having a lower selectivity than lipase $\mathrm{R}$, had a greater reaction rate. After $50 \%$ conversion, $48 \%$ of the starting material was $(R)-\mathbf{3 1}$, isolated with $99 \% e e$. The resolved alcohols were submitted to chemical group transformation. First, the epoxide was formed as a mixture of isomers: the compound with the anti disposition of the epoxide/hydroxymethyl group was the major product formed in $68 \%$ (the minor isomer was isolated in $13 \%$ yield). After, the epoxide was hydrolyzed to give the triol, and at last it was submitted to hydrazinolysis to give (-)-1 from (S)-31 and (+)-1 from (R)-31 [19]. 


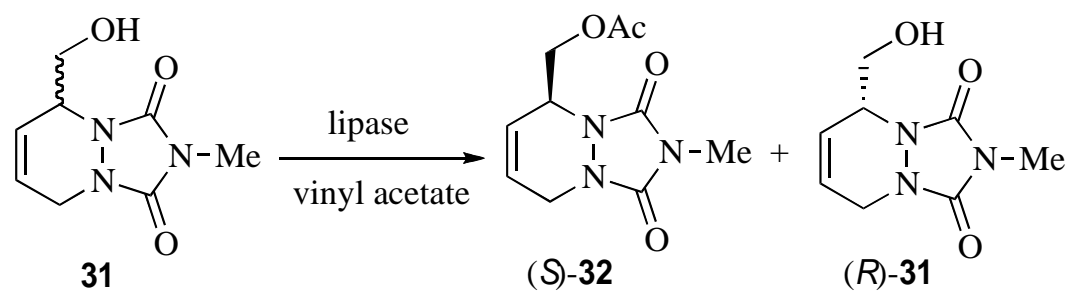

Scheme 9- Lipase-catalysed transesterification of racemic cycloadduct 31.

This strategy has an overall yield of $18 \%$ after 5 steps, $9 \%$ yield to each enantiomer. The optical purity of the compounds 31 was carried out by means of esterification of the alcohols (-)-31 and (+)-31 with camphanoyl chloride in the presence of dimethylaminopyridine and triethylamine. The two diastereomeric forms differ substantially from one another in their ${ }^{1} \mathrm{H}$ NMR spectra.

1-Azagalactofagomine was synthetized from achiral 2,4-pentadien-1-ol (2) and MTAD by Diels-Alder cycloaddition followed by enzymatic resolution with lipase $\mathrm{R}$ as the key steps of the strategy to give compounds $(S)-\mathbf{3 1}$ and $(R)-\mathbf{3 1}$ [22]. Compound $(S)$-31 underwent epoxidation with $m$ chloroperoxybenzoic acid at $80{ }^{\circ} \mathrm{C}$ for $18 \mathrm{~h}$ affording a mixture of epoxides $\mathbf{3 3}$ and $\mathbf{3 4}$ in a 2:1 ratio, from which the major syn epoxide $\mathbf{3 3}$ was isolated in $42 \%$ yield, and then opened with $57 \%$ aqueous $\mathrm{HI}$ in acetic acid followed by in situ peracetylation with acetic anhydride to afford a mixture of acetylated iodides 35 and 36 in a $1(35): 3(36)$ ratio and $75 \%$ yield. The preference for the formation of $\mathbf{3 6}$ could be explained by geometrical constraints in the bicyclic system that are in favour of $3 R, 4 R$ diaxial opening. The mixture of acetates $\mathbf{3 5}$ and $\mathbf{3 6}$ was treated with silver acetate in $6 \%$ aqueous acetic acid and further acetylated with acetic anhydride and triethylamine affording a mixture of acetates 7 (37) : 3 (38) ratio. The formation of $\mathbf{3 7}$ as the major isomer was a drawback of this reaction. This was suppressed by using silver trifluoroacetate in $6 \%$ aqueous trifluoroacetic acid. The stereoselectivity was improved to 96 (38) : 4 (37) in $79 \%$ yield. Compound 38 contaminated with $4 \%$ of $\mathbf{3 7}$ was reacted with sodium methoxide in methanol followed by treatment with hydrazine hydrate at $100{ }^{\circ} \mathrm{C}$ to give 1-azagalactofagomine 39 in $56 \%$ yield for the last two steps [22]. (Scheme 10)

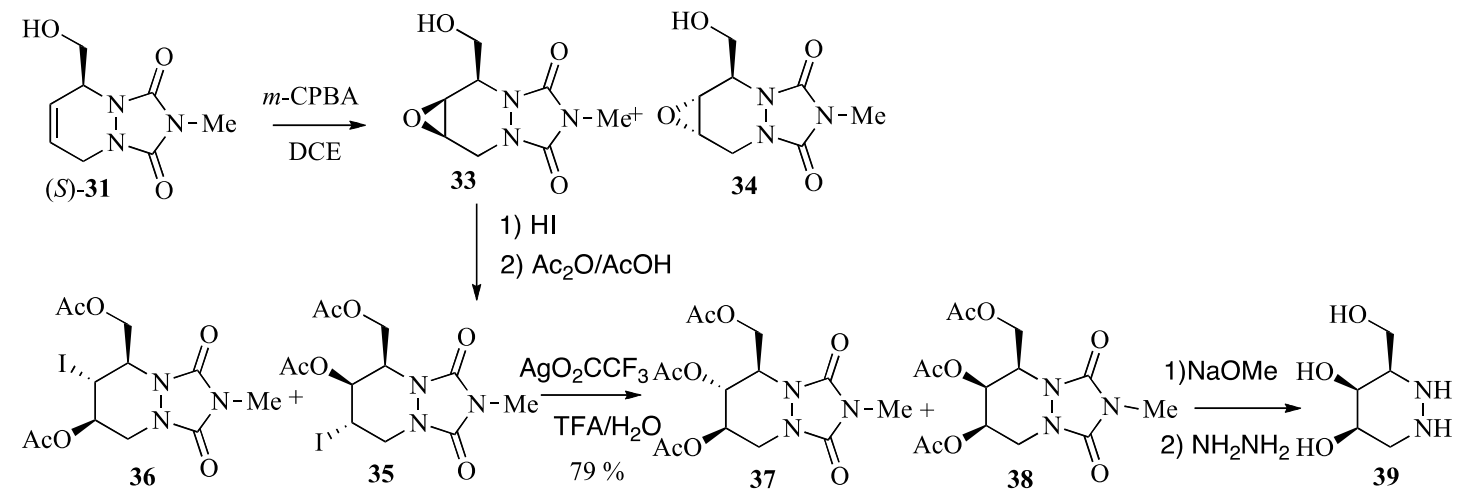

Scheme 10 - Synthesis of 1-Azagalactofagomine. 
Azagalactofagomine 39 was tested against a series of glycosidases. Not surprisingly compound $\mathbf{3 9}$ is a poor $\alpha$-glucosidase inhibitor, but in contrast is a strong $\beta$-glucosidase and $\beta$-galactosidase inhibitor of several sources, together with $\alpha$-galactosidase from green coffee beans. It is noteworthy that compound 39 is a slightly weaker inhibitor of $\beta$-galactosidase and $\beta$-glucosidase than is isogalactofagomine, but more potent than galactodeoxynojirimycine. In contrast, compound $\mathbf{3 9}$ is a stronger $\alpha$-galactosidase inhibitor than isogalactofagomine, but weaker than galactodeoxynojirimycine.

Table 3: Inhibition constants $\left(\mathrm{K}_{i}\right)$ in $\mu \mathrm{M}$ of target compounds to various enzymes, measured at $25^{\circ} \mathrm{C}$ and $\mathrm{pH} 6.8$.

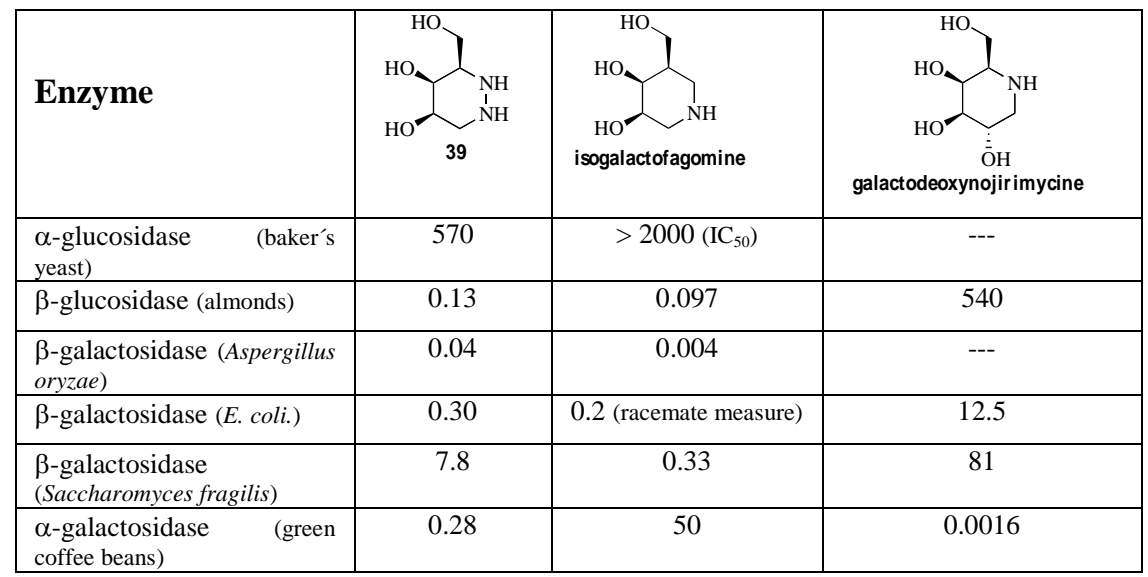

\subsection{Synthesis of homochiral 1-azafagomine, derivatives, and analogues}

Most of the reported synthesis of azasugars has carbohydrates, amino acids and tartaric acid as starting materials [23-25]. E.g. (-)-1-Azafagomine and (+)-1-azafagomine have also been prepared from L- and D-xylose respectively [26]. More recently the Diels-Alder cycloaddition as the key synthetic step, has been appealing to several authors. Combining Stoodleys's cycloaddition of $(E)-1-\left(2^{\prime}, 3^{\prime}, 4^{\prime}, 6^{\prime}-\right.$ tetra- $O$ acetyl- $\beta$-D-glucopyranosyloxy)-1,3-butadiene 40 to PTAD with Bols's olefin functionalization of the six-membered-ring and cleavage of the urazol moiety was obtained homochiral (-)-1-azafagomine. Cycloadduct 41 was prepared first in $70 \%$ yield and in a high degree of diastereoselectivity. Treatement of $\mathbf{4 1}$ with triethylsilane in trifluoroacetic acid according to Stoodley's protocol generated (-)-42 [27,28]. Epoxidation of compound (-)-42 with oxone/trifluoroacetone in the presence of sodium carbonate formed a 3:1 ratio of oxiranes, from which the major isomer $\mathbf{4 3}$ was crystallised. The epoxide moiety has an anti relationship to the ester group and was obtained in $65 \%$ yield. The epoxide 43 was opened in refluxing aqueous sulfuric acid with total regio- and stereo-selectivity to afford the trans-diol 44. On the other hand, osmilation of compound 42 produced the cis-diol 45 with total stereoselectivity. Selective reduction of trans-diol 44 and cis-diol 45 with sodium borohydride gave compounds 46 and 47, respectively. Reflux of these compounds with hydrazine hydrate gave the target compounds (-)-1-azafagomine (-)-1 in $14 \%$ overall yield and (+)-5-epi-1-azafagomine (+)-48 in $26 \%$ overall yield, from alkene (-)-42. (Scheme 11) 


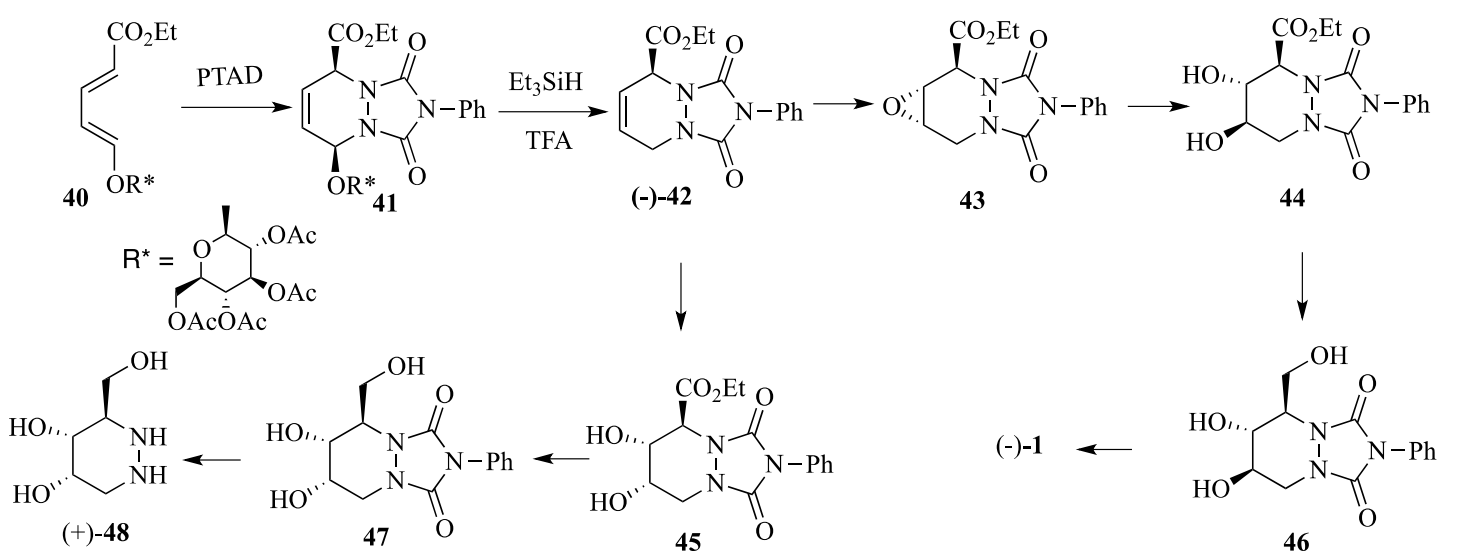

Scheme 11- Diastereoselective synthesis of 1-Azafagomine (-)-1 and 5-epi-1-azafagomine (+)-48.

It is known that 2- $N$-alkyl-1-azafagomines are poorer glycosidase inhibitors than 1-azafagomine [29], but 1-N-alkylated compounds display a higher inhibitory potential together with a largely enhanced $\alpha / \beta \square$ selectivity [30]. A series of $1-N$-alkylated 1 -azafagomines has been prepared to study the structure-activity relationship as glycosidase inhibitors. Scheme 12 represents the reaction sequence to obtain these compounds. An intermediate in the synthesis of 1-azafagomine from L-xylose, compound 49 was used as starting material. Alkylation occurs readily at $N-2$ because this atom is more basic, using compound 49 as the starting material the problem is avoided [12]. Alternatively, 1-azafagomine could be directly acetylated with acetic anhydride in methanol giving a 4:1 ratio of $1-\mathrm{N}$ - versus 2- $\mathrm{N}$ acetyl regio-isomers [17]. After separation the major compound 1- $N$-acetyl could be used as the starting material for the $2-\mathrm{N}$-alkylation. The introduction of the alkyl group at $\mathrm{N}-2$ was tried by direct alkylation with e.g. alkyl halides but the reactions failed due to the low basicity of this nitrogen atom. Alkylation occurs by reductive amination with an aldehyde in the presence of Pd (II). Under these conditions the benzyl groups were simultaneously cleaved to afford compounds 50. The acetyl group was removed by ion-exchange acidic resine and compounds $\mathbf{5 1}$ were obtained in good yields. (Scheme 12)

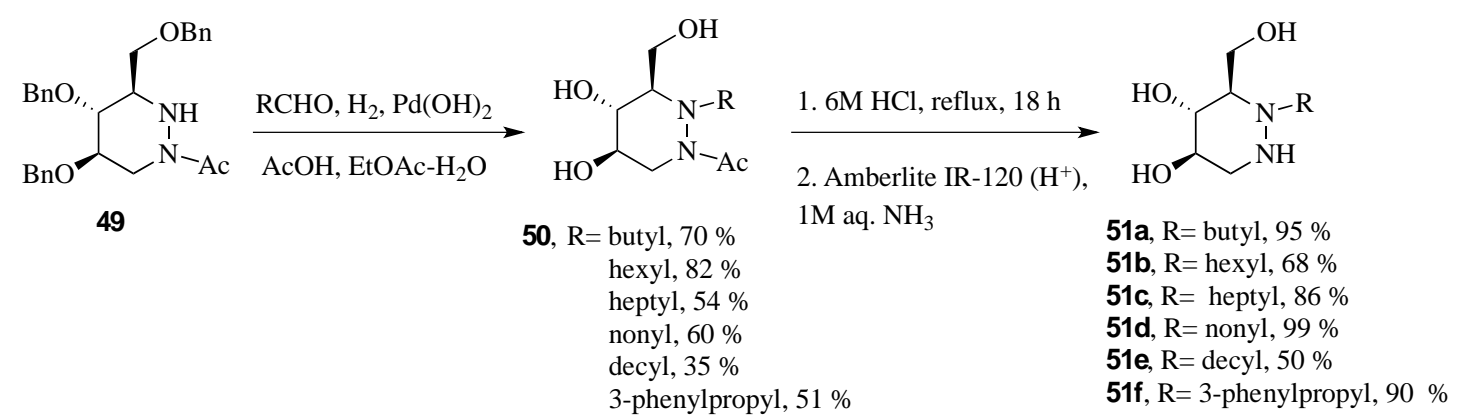

Scheme 12- Synthesis of 2- $N$-alkylated 1 -azafagomines.

Compounds 51 were investigated for inhibition of $\alpha$-glucosidase from yeast source and $\beta$-glucosidase 
from almonds. All compounds showed to be competitive inhibitors and the $\mathrm{K}_{i}$ were determined. The inhibition of $\alpha$-glucosidase was 10-30 times weaker than 1-azafagomine, showing that a free nitrogen atom at $N-2$ is important for the enzyme-substrate interaction. On the other hand, all compounds $\mathbf{5 1}$ revealed a much better activity against $\beta$-glucosidase than 1 -azafagomine. The $N$-hexyl (51b) and the $N$-(3-phenypropyl) (51f) are the preeminent compounds with five- to tenfold increased binding to $\beta$ glucosidase enzymes relatively to 1 -azafagomine. (See Table 4)

A new homochiral derivative of 1-azafagomine, 2- $N$-phenyl carboxamide hexahydropyridazine (-)-52 was obtained from the intermediate (-)-42 [31]. (Scheme 11) Treatment of compound (-)-42 with freshly opened $\mathrm{LiAlH}_{4}$ (15 eq.) selectively reduced one of the carbonyl groups of the phenyltriazolidinone moiety to afford compound (-)-52. (Scheme 13) The synthesis of its enantiomer, compound (+)-52, was obtained from 41 by epimerization of $\mathrm{H}-5$ inducted with $\mathrm{NEt}_{3}$ and $p$ chlorothiophenol to give compound 53. (Scheme 13) The glucosyl moiety was removed afterwards with triethylsilane in trifluoroacetic acid to yield (+)-42 in $84 \%$. The reactive sequence followed the same route of the levorotatory isomer (-)-42 being obtained (+)-2- $N$-phenyl carboxamide hexahydropyridazine (+)-52 from enantiomer (+)-42. (Scheme 13) Compounds (-)-2-N-phenyl carboxamide hexahydropyridazine (-)-52 and (+)-2- $N$-phenyl carboxamide hexahydropyridazine (+)-52 were obtained in $29 \%$ and $10 \%$ overall yield, starting from compounds $\mathbf{4 1}$ and $\mathbf{5 3}$ respectively.

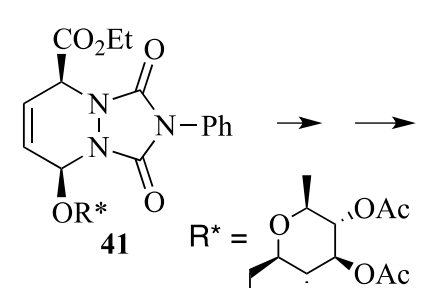

$v^{\mathrm{NEt}} \mathrm{ClC}_{6} \mathrm{CH}_{4} \mathrm{SH}$<smiles>CCOC(=O)C1C=CC([O-])C(=O)N1C(=O)NI</smiles>

53 $\mathrm{AcO} A \mathrm{Ac}$<smiles>CCOC(=O)[C@@H]1[C@@H](O)[C@H](O)Cn2c(=O)n(-c3ccccc3)c(=O)n21</smiles>

$(-)-44$<smiles>O=C(Nc1ccccc1)N1NC[C@@H](O)[C@H](O)[C@H]1CO</smiles>

$(-)-52$

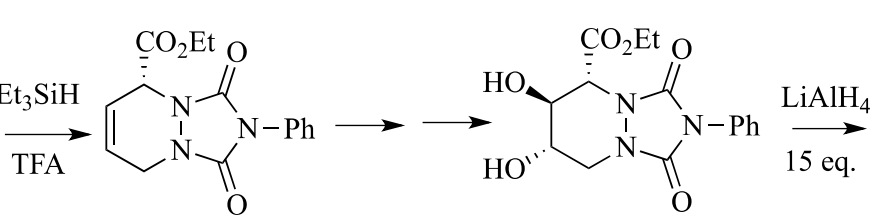

$(+)-42$

$(+)-44$<smiles>O=C(Nc1ccccc1)N1NC[C@@H](O)[C@H](O)[C@H]1CO</smiles>

$(+)-52$

Scheme 13- Synthesis of (-)- and (+)-2- $N$-carboxamide hexahydropyridazines.

Both enantiomers (-)-52 and (+)-52 were tested against yeast $\alpha$-glucosidase and almonds $\square \beta$ glucosidase. Curiously the $\alpha$-glucosidase inhibition of compound (-)-52 display a $\mathrm{K}_{i}=3.36 \mu \mathrm{M}$ and (+)-52 a relatively similar result $\mathrm{K}_{i}=10.6 \mu \mathrm{M}$, in strict contradiction with the results of $\alpha$-glucosidase inhibition in the (-)-2- $N$-alkyl hexahydropyridazine derivatives. Another curious achievement is the question raised against the established knowledge that there is a big difference between the left- and dextrorotatory enantiomers in respect to the inhibition activity. In this case it just do not apply. It was 
found in the past that the dextrorotatory 1-azafagomine was practically inactive towards $\alpha$ - and $\beta$ glucosidases [26]. The relationship of inhibition activities between the two enantiomers (-)-52 and (+)$\mathbf{5 2}$ is ca 1:3, in favour of levorotatory isomer relatively to $\alpha$-glucosidase from backer's yeast source, and $\square \square c a$ 1:2 relatively to $\beta$-glucosidase from almonds. The interaction of both enantiomers (-)-52 and (+)-52 with $\alpha$-glucosidase was studied by molecular modelling. The aromatic ring seems to efficiently pack into a hydrophobic pocket in the enzyme's active site, which could be responsible for the improved binding affinity of these compounds in relation to underivatized (-)-1-azafagomine and (+)-1azafagomine [31].

Reaction of optically active compound $\mathbf{3 4}$ with $\mathrm{HI}$ in acetic acid gave a single iodinated product $\mathbf{5 4}$, with the attack occurring at the more accessible carbon atom. The product $\mathbf{5 4}$ was obtained with $73 \%$ yield. This iodide was subjected to radical reduction with tribuylstannane-azobisisobutyronitrile $\left(\mathrm{Bu}_{3} \mathrm{SnH}-\mathrm{AIBN}\right)$ to give the 4-deoxy derivative 55 in $65 \%$ yield. Deacetylation with sodium methoxide in methanol followed by hydrazinolysis gave compound $\mathbf{5 6}$ in $57 \%$ yield. The diastereomer of compound 34, epoxide 33 under HI in acetic acid followed by treatment with acetic anhydride yield two regio-isomers: compounds $\mathbf{3 5}$ and 36. These were subjected to the reductive conditions to which compound 54 was submitted, giving a mixture of compounds 57 and $\mathbf{5 8}$. The mixture was separated to give $\mathbf{5 8}$ in $46 \%$ yield and $\mathbf{5 7}$ in $21 \%$ yield. After deacetylation and hydrazinolysis the deoxycompounds 59 and 60 were obtained in $65 \%$ and $63 \%$ yield, respectively [13]. (Scheme 14)

2) 34 $73 \%$ 54 55 $57 \% \quad \mathbf{5 6}$

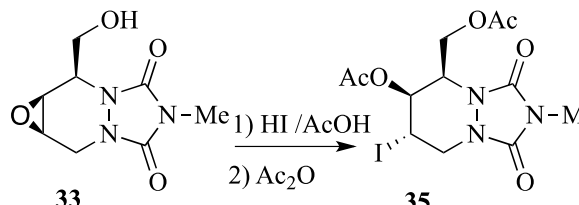

33 35

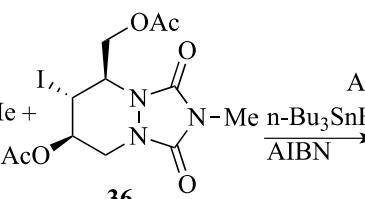
36<smiles>CC(=O)OCC1C(O)CCN2C(=O)NC(=O)C12O</smiles>

60

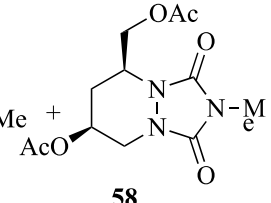

1) $\mathrm{MeONa}$ 2) $\mathrm{NH}_{2} \mathrm{NH}_{2} \cdot \mathrm{H}_{2} \mathrm{O}$<smiles>OCC1CC(O)CNN1</smiles>

59

Scheme 14- Synthesis of deoxyazasugars 56, 59 and 60. 
Table 4: Inhibition constants $\left(\mathrm{K}_{i}\right)$ in $\mu \mathrm{M}$ of target compounds with various enzymes, measured at $25^{\circ} \mathrm{C}$ and $\mathrm{pH} 6.8$, unless noted otherwise.

\begin{tabular}{|c|c|c|c|}
\hline Compound & $\begin{array}{c}\alpha \text {-glucosidase } \\
\text { (backer's yeast) }\end{array}$ & $\begin{array}{c}\beta \text {-glucosidase } \\
\text { (almonds) }\end{array}$ & $\alpha / \beta$ selectivity \\
\hline & $6.90(\mathrm{pH} 6.8)$ & $0.32(\mathrm{pH} 6.8)$ & 22 \\
\hline
\end{tabular}

1-Azagulofagomine analogue $\mathbf{6 1}$ was obtained in a 5 steps strategy with $25 \%$ overall yield [32]. The key step is an asymmetric hetero Diels-Alder cycloaddition of chiral 1-p-tolylsulfinyl-1,3-pentadiene 62 to MTAD (Scheme 15). The reaction occurs at $-10^{\circ} \mathrm{C}$ generating cycloadduct 63 , which underwent a $[2,3]$ sigmatropic rearrangement of the sulfinyl group leading to compound 64 . Compound 64 was treated with trimethylphosphite as a thiophilic agent to form the alcohol $\mathbf{6 5}$ in $98 \%$ yield and $91 \%$ ee [33]. Compound $\mathbf{6 5}$ was silylated with ${ }^{t}$ butyldimethylsilyl triflate in presence of triethylamine to give the derivative 66. Oxidation of the double bond with osmium tetroxide and $\mathrm{N}$-methylmorpholine oxide gave a mixture of cis diols in a ratio 9:1 and $80 \%$ de, from which the major isomer $\mathbf{6 7}$ was isolated in $46 \%$. Surprisingly the same compound $\mathbf{6 7}$, but in better yield and higher $d e$ (64\% yield, $98 \%$ de) was obtained by epoxidation of the double bond with 3-methyl-3-trifluoromethyldioxirane followed by hydrolysis under basic conditions. 


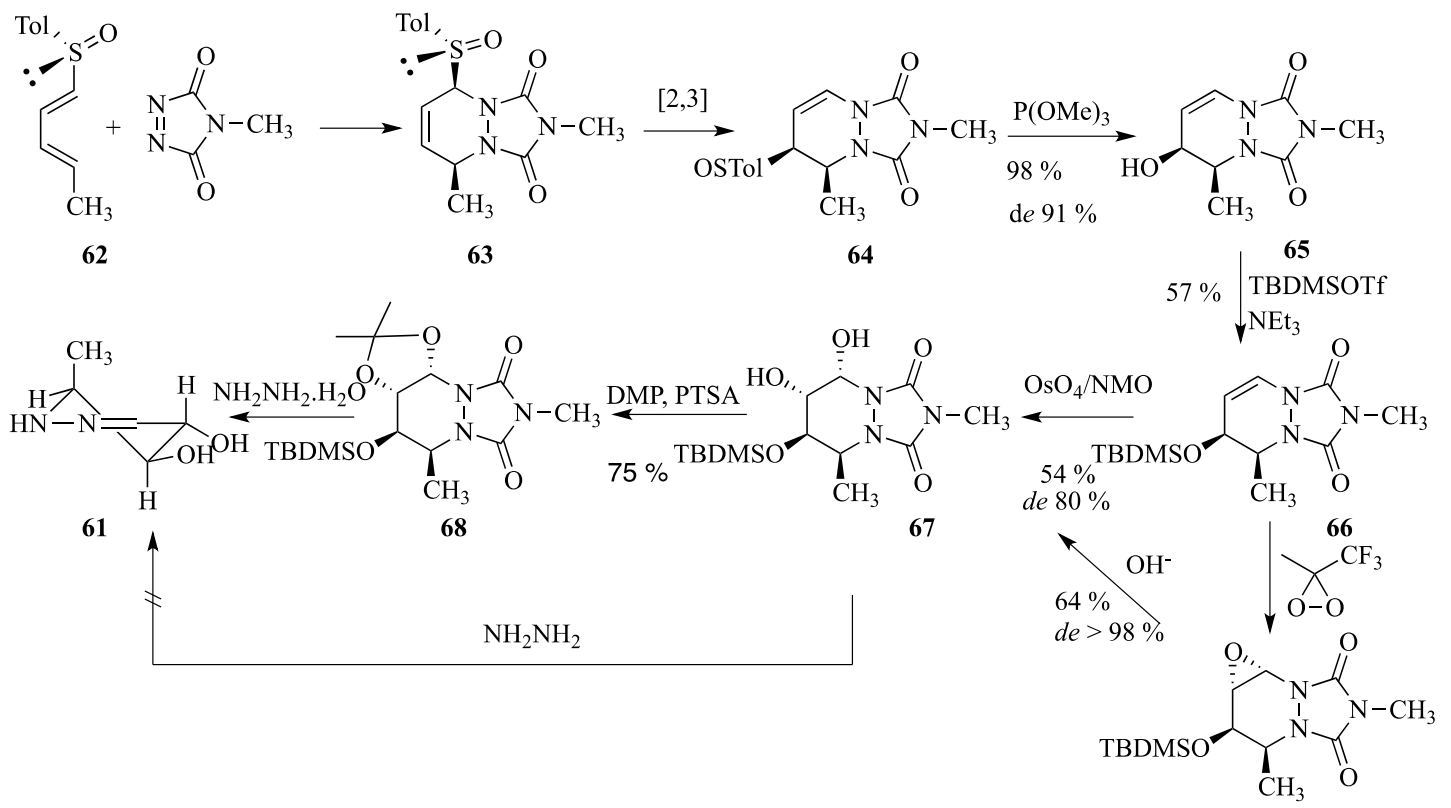

Scheme 15- Formation of 1-azagulofagomine analogue 61.

Although hydrazine has been used to cleave $N$-methyl urazole units in several compounds of type $\mathbf{6 7}$ $[19,34]$, it did not work in compound 67 . To overcome this problem, the two vicinal hydroxyl groups of diol 67 were protected as an acetal to form 68 , which was then treated with $\mathrm{NH}_{2} \mathrm{NH}_{2}$ to give a 1azagulofagomine analogue $\mathbf{6 1}$ in quantitative yield. (Scheme 15)

An explanation for the unexpected result obtained in the epoxide opening was suggested to be an assisted opening by a lone pair of electrons of the oxygen in the OTBS group, that would occur before the nucleophilic attack promoted by the hydroxide anion, according to figure 6 .
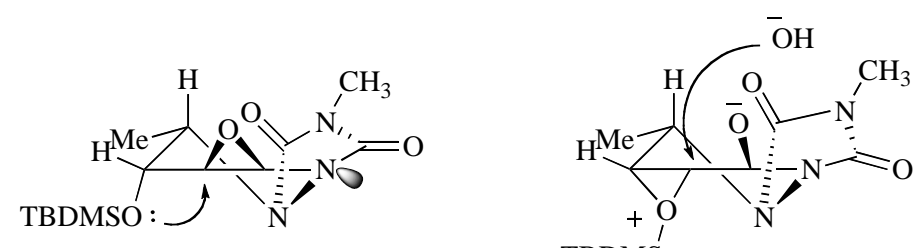

TBDMS

Figure 6- Assistance of the OTBS group in the epoxide opening leading to cis diol 70.

No glycosidase inhibition study was found for compound 64.

\section{References:}

[1] Scott, L.J.; Spencer, C.M. Miglitol: A Review of its Therapeutic Potential in Type 2 Diabetes Mellitus. Drugs, 2000, 59, 521-549.

[2] Bernacki, R.J.; Niedbala, M.J.; Koerytnyk, W. Glycosidases in cancer and invasion. Cancer and Metastasis Reviews, 1985, 4, 81-101.

[3] Alper, J. Searching for Medicine's Sweet Spot. Science, 2001, 291, 2338-2343.

[4] Jacob, G.S.; Scudder, P.; Butteres, T.D.; Jones, I.; Tiemeier, D.C. In: Natural Products as Antivaral Agents; Chu, C.K. and Cutler, H.G. Ed.; Plenum Press, New York, 1992; pp 137-151.

[5] Karpas, A.; Fleet, G.W.J.; Dwek, R.A.; Fellows, L.E.; Tymes, A.S.; Petursson, S.; Namgoong, S.K.; Ramsden, N.G.; Jacob, G.S.; Rademacher, T.W. Aminosugar derivatives as potential anti-human immunodeficiency virus 
agents. Proc. Natl. Acad. Sci. U.S.A., 1988, 85, 9229-9233.

[6] Laver, W.G.; Bischofberger, N; Webster, R.G. Disarming flu viruses. Sci.Am., 1999, 280, 78-87.

[7] Tian, Y-S.; Joo, J-E.; Kong, B-S.; Pham, V-T.; Lee, K-Y.; Ham, W-H. Asymmetric synthesis of (-)swainsonine. J. Org. Chem., 2009, 74, 3962-3965.

[8] Heightman, T.D., Vasella, A.T., Recent insights into inhibition, structure, and mechanism of configurationretaining glycosidases. Angew. Chem. Int. Ed., 1999, 38, 750-770.

[9] Zechel, D.L., Withers, S.G. Glycosidase Mechanisms: Anatomy of a Finely Tuned Catalyst. Acc. Chem. Res., 2000, 33, 11-18.

[10] Bols, M. 1-Azasugars, apparent transition state analogues of equatorial glycoside formation/cleavage. Acc. Chem. Res., 1998, 31, 1-8.

[11] Bols, M.; Hazell, R.G.; Thomsen, Ib B. 1-Azafagomine: a hydroxyhexahydropyridazine that potently inhibits enzymatic glycoside cleavage. Chem. Eur. J., 1997, 3, 940-947.

[12] Jensen, H.H.; Lyngbye, L.; Jensrn, A.; Bols, M. Stereoelectronic substituent effects in polyhydroxylated piperidines and hexahydropyridazines. Chem. Eur. J., 2002, 8, 1218-1226.

[13] Jensen, H.H.; Jensen, A.; Hazell, R.G.; Bols, M. Synthesis and investigation of L-fuco- and D-glucuronoazafagomine. J. Chem. Soc., Perkin Trans. 1, 2002, 1190-1198.

[14] Tsuchiya, T. Chemistry and developments of fluorinated carbohydrates. Adv. Carbohydr. Chem. Biochem., 1990, 48, 91-277.

[15] Von Itzstein, M.; Wu, W.-Y.; Kok, G.B.; Pegg, M.S.; Dyason, J.C.; Jin, B.; Phan, T.V.; Smythe, M.L.; Oliver, S.W.; Colman, P.M.; Varghese, J.N.; Ryan, D.M.; Woods, J.M.; Bethell, R.C.; Hotham, V.J.; Cameron, J.M.; Penn, R.C. Rational design of potent sialidase-based inhibitors of influenza virus replication. Nature, 1993, 363, 418-423. [16] Lohse, A.; Jensen, H.H.; Bach, P.; Bols, M. Synthesis of 3-substituted isofagomine analogues using an unusual syn hydrogenation reaction. J. Chem. Soc., Perkin Trans. 1, 2000, 659-665.

[17] Thomsen, Ib; Ernholt, B.V.; Bols, M. Synthetic studies of fluorinated analogues of 1-azafagomine: remarkable nucleophilic substitution of fluorine by hydrazine. Tetrahedron, 1997, 53, 9357-9364.

[18] Søndergaard, K.; Liang, X.; Bols, M. Synthesis of 5-azacastanospermine, a conformationally restricted azafagomine analogue. Chem. Eur. J., 2001, 7, 2324-2331.

[19] Liang, X.; Bols, M. Chemoenzymatic synthesis of enantiopure 1-azafagomine. J. Org. Chem., 1999, 64, 8485-8488.

[20] Ling, L.; Ozaki, S. Enzyme aided synthesis of D-myo-inositol 1,4,5-trisphosphate. Tetrahedron Lett., 1993, 34, 2501-2504.

[21] Altenbach, H.-J.; Blanda, G. A novel building block for the synthesis of isofagomine analogues. Tetrahedron: Asymmetry, 1998, 9, 1519-1524.

[22] Jensen, H.H.; Bols, M. Synthesis of 1-azagalactofagomine, a potent galactosidase inhibitor. J. Chem Soc., Perkin Trans 1, 2001, 905-909.

[23] Alves. M.J.; Azoia, N.G. "Stereoselective Methods towards the Synthesis of Azasugars”, In: Stereochemistry Research Trends, M.A. Horvat and J.H. Golob Ed.; Nova Science Publishers, 2008; pp 1-50.

[24] Afarinkia, K.; Bahar, A. Recent advances in the chemistry of azapyranose sugars. Tetrahedron: Asymmetry, 2005, 16, 1239-1287.

[25] Asano, N.; Nash, R. J.; Molyneux, R.J.; Fleet, G.W.J. Sugar-mimic glycosidase inhibitors: natural occurrence, biological activity and prospects for therapeutic application. Tetrahedron: Asymmetry, 2000, 11, 1645-1680.

[26] Ernholt, B.V.; Thomsen, Ib B.; Lohse, A.; Plesner, I.W.; Jensen, K.B.; Hazell, R.G.; Liang, X.; Jakobsen, A.; Bols, M. Enantiospecific synthesis of 1-azafagomine. Chem. Eur. J., 2000, 6, 278-287.

[27] Aspinall, I.H.; Cowley, P.M.; Mitchell, G.; Stoodley, R.J. Asymmetric synthesis of (3S)-2,3,4,5tetrahydropyridazine-3-carboxylic acid. J. Chem. Soc., Chem. Commun., 1993, 1179-1180.

[28] Cowley, P.M.; Stoodley, R. J. Regio- and stereo-selective intermolecular interceptions of a conjugated $N$ acylhydrazonium ion. Tetrahedron Lett., 1994, 35, 7853-7856.

[29] Lohse, A.; Jensen, K.B.; Bols, M. The first combinatorial library of azasugar glycosidase inhibitors. Tetrahedron Lett., 1999, 40, 3033-3036.

[30] Lopez, O.L.; Bols, M. Anomer-selective glycosidase inhibition by 2- $N$-alkylated 1-azafagomines. ChemBioChem., 2007, 8, 657-661.

[31] Alves, M.J.; Costa, F.T.; Duarte, V.C.M.; Fortes, A.G.; Martins J.A.; Micaelo, N.M. Advances in the Synthesis of homochiral (-)-1-azafagomine and (+)-5-epi-1-azafagomine. 1- $N$-phenyl carboxamide derivatives of both enantiomers of 1-azafagomine: leads for the synthesis of active $\alpha$-glycosidase inhibitors. J. Org. Chem. 2011, $76,9584-9592$.

[32] Arroyo, Y.; Rodriguez, J.F.; Santos, M.; Sanz Tejedor, M.A.; Vaca, I.; Garcia Ruano, J.L. Asymmetric synthesis of $(3 S, 4 R, 5 R)$-4,5-dihydroxy-3-methyl-2,3,4,5-tetrahydropyridazine: a formal synthesis of 1azagulofagomine analogues. Tetrahedron: Asymmetry, 2004, 15, 1059-1063.

[33] Carreño, M. C.; Cid, M. B.; García Ruano, J. L.; Santos, M. Short enantioselective approach to substituted triazolopyridazines from $[(S) R]-1-(1 E, 3 E)-1-p$-tolylsulfinyl-1,3-pentadiene. Tetrahedron Lett., 1998, 39, 1405 1408.

[34] Hansen, S. U.; Bols, M. Synthesis of labelled 1-azafagomine. J. Chem. Soc., Perkin Trans. 1, 1999, 33233325 . 
